\title{
Groundwater Recharge and Aquifer Transmissivity of Crystalline Basement Terrain
}

\author{
Olanrewaju Akinfemiwa AKANBI \\ Department of Earth Sciences, Ajayi Crowther University, Oyo, PMB 1066, Oyo Town Nigeria
}

\begin{abstract}
It is known that substantial groundwater bearing zones can develop within the weathered and fractured units of impermeable crystalline rocks if there is a good and recurrent source of recharge. On account of this, eighty-two geo-electric soundings were carried out to determine the degree and extent of weathering and bedrock fracturing; and in addition, twenty-one single -well (constant discharge) pumping tests were also conducted for the estimation of the transmissivity of the water-bearing zones across the various bedrock terrains of Ibarapa areas of southwestern Nigeria. Weathering development was found to be more pronounced in areas underlain by amphibolite and gneisses bedrocks with a regolith thickness range of $4.4-47.5 \mathrm{~m}$ (av.18.41 m) as compared to the relatively shallower soil horizon range of $2.4-23.6 \mathrm{~m}$ (av. $12.03 \mathrm{~m}$ ) that developed upon light coloured rocks of migmatite and granites. The recharge potentials as inferred from the total longitudinal conductance indicated that there is likelihood of better water infiltration in areas underlain by migmatite and granites with $0.02-0.60$ mhos. The discharging areas underlain by amphibolite and gneisses with higher conductance of $0.01-1.42$ mhos were characterized by thicker and finer grained overburden unit and more numerous bedrock fractures that sustain reliable groundwater yield. Only one-third of the boreholes were sustainable with transmissivities of $7.75-0.50$ $\mathrm{m}^{2} /$ day; these prolific boreholes were mostly within amphibolite and gneisses terrains. Change in the drawdowns during pumping was between 1.7 and $14 \mathrm{~m}$, while the groundwater yield was between 93.58 and $32.78 \mathrm{~m}^{3} / \mathrm{day}$.
\end{abstract}

Keywords: Groundwater recharge, transmissivity, sustainable yield

DOI: $10.7176 / \mathrm{JEES} / 9-10-13$

Publication date:October $31^{\text {st }} 2019$

\section{Introduction}

In Nigeria, groundwater occurrence seems to be restricted by the fact that more than half of the country is underlain by crystalline rocks (Offodile, 2002), which ordinarily have no groundwater potential, except when they are fractured, or where there is development of significant regolith thickness over the fresh basement (Singhal and Gupta, 1999; Akanbi, 2018a). Consequently, the development of the groundwater bearing zones is complex and erratic in crystalline basement terrains, and the understanding of the concept of the weathered-fractured units is pertinent in these areas.

The study area which is entirely underlain by hard- brittle crystalline rocks of Pre-Cambrian era (NGSA, 2009) is located in Ibarapa region of southwestern Nigeria (Fig. 1). Most of the constituent communities in Ibarapa are largely rural and the residents rely mostly on groundwater supply; not only for domestic needs, but also for agricultural purposes. Hundreds of hand-pump boreholes have been provided for these communities, and many boreholes are being drilled on yearly basis. However, even with this provision, availability of potable water is still inadequate, largely due to the unsustainable yield of many of the functioning boreholes. For location of groundwater bearing zones, appropriate geophysical methods are applicable and has increased the understanding of the hydrology of the weathered-fractured concepts in basement areas (Olorunfemi, and Olorunniwo, 1985, 1990; Olayinka and Mbachi, 1992). Consequently, constructions of boreholes with good water yield are now feasible in basement areas. Even then, there is need for quantitative estimation of aquifer parameters for ensuring sustainable safe yield of the water-bearing zones. Therefore, the understanding of the groundwater potential of the regolith units and the estimable hydraulic characteristics of the water bearing zones will be a great contribution to the groundwater development and management policy where basement aquifers are being exploited strategically in town water supply scheme.

\subsection{Geology of the Study Area}

Four principal crystalline basement rocks can be identified from the study of the outcropping sections in the areas. 
These include migmatite, gneisses, amphibolite and granites (Akanbi, 2017) (Fig. 2). Lastly, there are latter intrusions of pegmatites, aplites and the quartz veins. The intrusions mostly occur as undifferentiated intercalations within the older rocks. The structural features of the crystalline rocks as studied from the outcropping sections and the application of remote sensing principles using appropriate satellite imageries revealed prominent linear trends of NNW-SSE and NE-SW on the gneisses, NW-SE and NE-SW on porphyritic granite and NN-SS, NWW-SEE trend on migmatites (Akanbi, 2018b). These linear features are the fractures, faults and joints in rocks which are important for water storage and transmission.

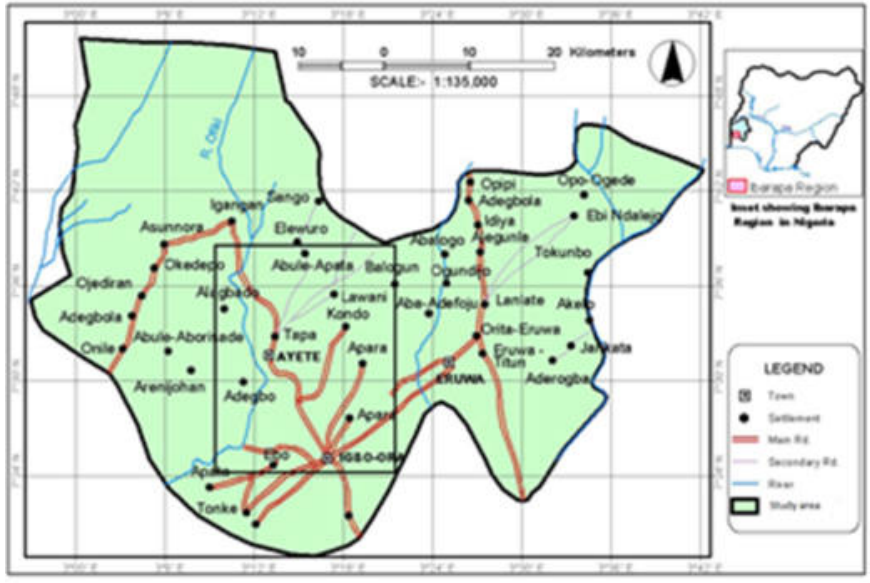

Fig. 1: Location map of Ibarapa region showing the study area

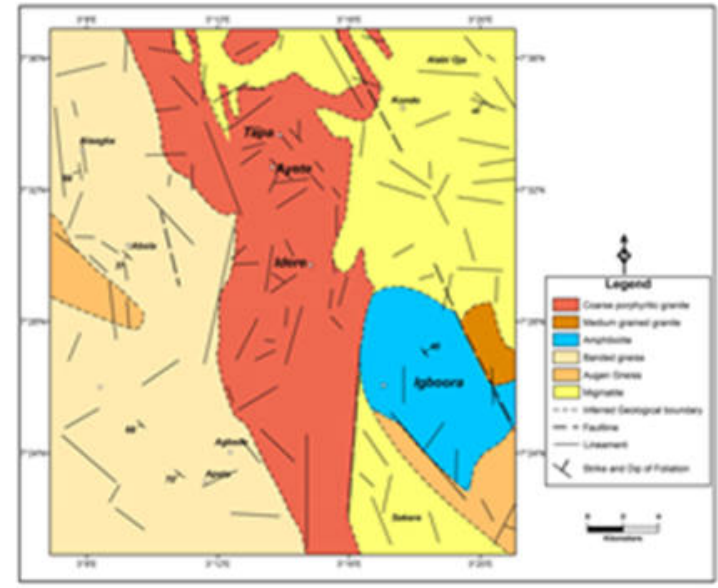

Fig. 2: Geological map and structural lineaments of the study area (Akanbi, 2018b)

\section{Methods}

\subsection{Geo-electrical surveys and groundwater recharge potential}

The Schlumberger electrode array was used for the conduct of 82 vertical electrical soundings (VES) conducted across the area for studying the weathered-fractured units on the various underlying crystalline rocks in the area. VES is an electrical resistivity method and from the interpretation of the primary geo-electric parameters, which are the thickness and the layer resistivity the extent and the intensity of decomposition of the fresh basement can be inferred (Olorunfemi, and Olorunniwo, 1985, 1990). Longitudinal conductance, which is one of the secondary resistivity parameters known as Dar Zarrouk parameters was employed for studying groundwater recharge of the area (Oladapo and Akintorinwa, 2007; Abiola et. al., 2009; Aweto; 2011). The background concept of Dar Zarrouk parameters assumes that the earth is parallel with ' $n$ ' layer and the flow of current through such sequence is controlled by individual layer resistivities and their respective thicknesses. When a number of layers are involved 
in a geoelectric section, their total longitudinal conductance $\mathrm{S}$ and total transverse resistance $\mathrm{T}$ as given by Sabnavis and Patangay, 2006 are: $\mathrm{S}=\sum \mathrm{hi} / \rho$ i and $\mathrm{T}=\sum$ hi. $\rho$ i where $\mathrm{S}=$ the total longitudinal conductance, $\mathrm{T}=$ the total transverse resistance and hi and $\rho \mathrm{i}$ are the thicknesses and resistivities of $i=1,2,3 . . n$ layer.The potential for water conductance and water transmission across and through the layered sequence are quantified and explained by these parameters, most especially the estimated total longitudinal conductance denoted by ' $\mathrm{S}$ '. The total longitudinal conductance, S typify the potential for groundwater recharge in each VES location through surface water (mostly meteoric) infiltration across the overburden units.

\subsection{Groundwater yield of the water-bearing zones}

The transmissivities of the water-bearing zones were estimated from the single-well constant pumping tests carried out on boreholes that penetrated the various bedrocks underlying the area. Papadopulos and Cooper (1967) observed that the influence of well-bore storage on the drawdown in a well decreases with time and becomes negligible at $\mathrm{t}>25 \mathrm{rc} 2 / \mathrm{T}$, where $\mathrm{rc}$ is the radius of the unscreened part of the well, where the water level is changing and $\mathrm{T}$ is the transmissivity. Wells with pumping time exceeding the required time $\mathrm{t}$ are regarded as sustainable ones and the pumping tests data of these wells with sustainable discharge were analysed by Jacob's straight line method to obtain reliable estimates of transmissivities from the equation: $\mathrm{T}=2.3 \mathrm{Q} / 4 \pi \Delta \mathrm{s}$; where, $\mathrm{T}=$ transmissivity of the aquifer, $\mathrm{Q}=$ pumping rate and $\Delta \mathrm{s}=$ change in drawdown per log cycle of time.

The Jacob's straight line method seems to be the most applicable for determining the aquifer transmissivity for a constant discharge single-well pumping tests in basement terrain. This is because there is no need to correct the observed drawdowns for well losses, since the aquifer transmissivity is determined from $\Delta \mathrm{s}$, which are not influenced by well losses as long as the discharge is constant. Also, it is applicable to partially penetrating well provided that the late time data are used (Kruseman and de Ridder, 2000).

\section{$3 \quad$ Results and Discussion}

\subsection{Weathering development and bedrock fracturing of various crystalline rocks}

The dominant VES curve is the 3-layer H type; characterised by relatively more conductive middle layer that terminates on more resistive infinite layer. The infinite layer is partially weathered, fractured or fresh. Only seven curves representing $8.5 \%$ of the total VES curves generated were characterised with more than 3-layer geoelectric sequence. The statistics of the interpreted geo-electric parameters are presented in Table 1, while the frequency distribution of the lithologic units of the weathered layer for the various bedrocks are illustrated in Fig. 3.

In areas underlain by amphibolite, the regolith thickness ranges from $4.40-39.40 \mathrm{~m}$ with an average (av.) of 18.23 $\mathrm{m}$. The degree of bedrock fractures was quantified to be about $64 \%$ of all the sounding points on amphibolite terrains. From the resistivity values (Table 1), the saprolite layers upon amphibolite are more fine grained soils at an average value of $53.1 \Omega \mathrm{m}$ when compared to that of other bedrocks. The development of finer saprolite layer on amphibolite is attributable to the fine grained texture and relative abundant of dark coloured minerals of the amphibole rich rocks. The resistivities of the fresh or non-weathered amphibolite bedrock were mostly below 2500 $\Omega \mathrm{m}$, except at areas laden by quartz boulders where the value ranged from about $4500-5500 \Omega \mathrm{m}$. The weathering development at the western section in amphibolite terrain is markedly characterised by thick saprolite layer terminating on partially weathered bedrock, while there is progressive decrease in the thickness of the middle layer eastward terminating on fresh bedrock. 
Table 1. Statistics of the geo-electric parameters of the various bedrocks

\begin{tabular}{|c|c|c|c|c|c|}
\hline $\begin{array}{l}\text { Rock types } \\
\text { (No. of } \\
\text { VES) }\end{array}$ & Geo-electric parameters & Min & Max & Mean & Std dev. \\
\hline \multirow{4}{*}{$\begin{array}{l}\text { Amphibolite } \\
\text { (25) }\end{array}$} & Resistivity of weathered layer $(\Omega \mathrm{m})$ & 9.10 & 225.20 & 53.10 & 53.30 \\
\hline & Resistivity of bedrock $(\Omega \mathrm{m})$ & 105.70 & 5472.70 & 1515.59 & 1531.27 \\
\hline & Total regolith thickness (m) & 4.40 & 39.40 & 18.23 & 9.28 \\
\hline & Total longitudinal conductance $\left(\Omega^{-1}\right)$ & 0.02 & 1.42 & 0.45 & 0.33 \\
\hline \multirow{4}{*}{$\begin{array}{c}\text { Gneisses } \\
\text { (19) }\end{array}$} & Resistivity of weathered layer $(\Omega \mathrm{m})$ & 18.80 & 810.60 & 117.95 & 177.14 \\
\hline & Resistivity of bedrock $(\Omega \mathrm{m})$ & 196.60 & 9601.40 & 1814.92 & 2242.51 \\
\hline & Total regolith thickness (m) & 6.30 & 59.00 & 18.49 & 11.60 \\
\hline & Total longitudinal conductance $\left(\Omega^{-1}\right)$ & 0.01 & 1.06 & 0.28 & 0.26 \\
\hline \multirow{4}{*}{$\begin{array}{l}\text { Migmatite } \\
\text { (18) }\end{array}$} & Resistivity of weathered layer $(\Omega \mathrm{m})$ & 28.10 & 1903.00 & 204.39 & 442.47 \\
\hline & Resistivity of bedrock $(\Omega \mathrm{m})$ & 191.30 & 6863.30 & 1488.25 & 1628.95 \\
\hline & Total regolith thickness (m) & 4.60 & 23.60 & 12.77 & 5.18 \\
\hline & Total longitudinal conductance $\left(\Omega^{-1}\right)$ & 0.02 & 0.60 & 0.23 & 0.17 \\
\hline \multirow{4}{*}{$\begin{array}{l}\text { Porphyritic } \\
\text { granite } \\
\text { (20) }\end{array}$} & Resistivity of weathered layer $(\Omega \mathrm{m})$ & 26.50 & 294.00 & 93.03 & 72.04 \\
\hline & Resistivity of bedrock $(\Omega \mathrm{m})$ & 547.20 & 29903.80 & 4601.23 & 6494.13 \\
\hline & Total regolith thickness (m) & 2.40 & 20.80 & 11.29 & 4.59 \\
\hline & Total longitudinal conductance $\left(\Omega^{-1}\right)$ & 0.05 & 0.38 & 0.15 & 0.11 \\
\hline
\end{tabular}

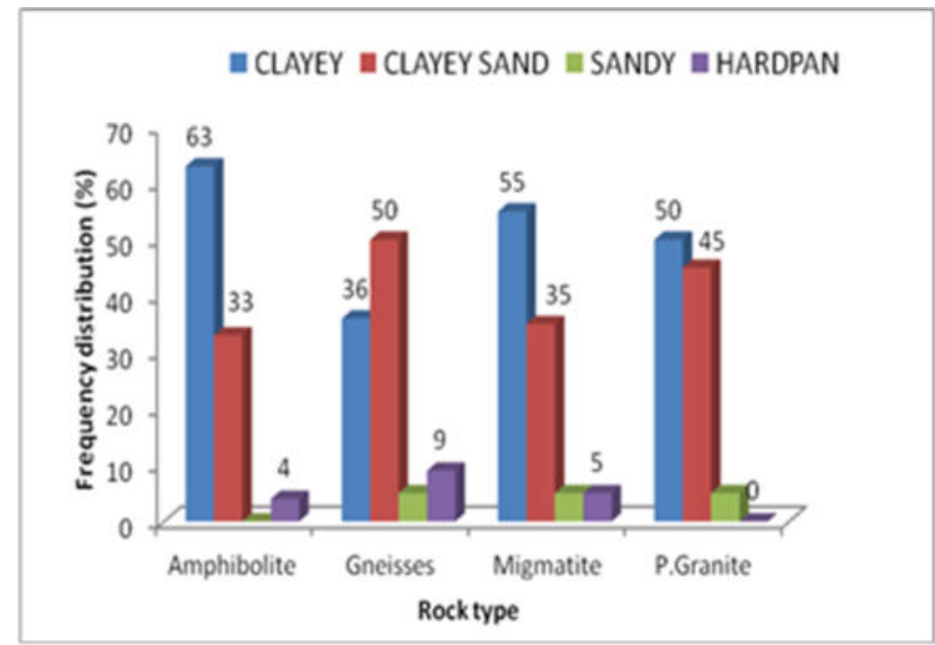

Fig. 3: Lithologic distribution of the weathered layer

Areas underlain by gneisses have the thickest weathered layer development with a range of $6.3-59.0 \mathrm{~m}$ (av.18.49m). These areas were also characterised by wide range of elevations of $81-199 \mathrm{~m}$ (av.141.61m) above the sea level, and have the largest elevation mean dispersion of $31.5 \mathrm{~m}$. The geomorphology includes; flood plains (located in the SW portion), low-lying and highlands in the central to NW parts of the study area. The thickest 
regolith units above $15 \mathrm{~m}$ were associated with the floodplain and highland areas. The lowland areas were characterised by moderate regolith unit ranging from 5-15 m. In respect of bedrock fracturing, $74 \%$ of the total VES surveys conducted on gneisses terminated on fractured or partly weathered basement. With this, the degree of rock decomposition is the highest compared to other bedrocks, though on the average, the extent of the weathering development is close to what is interpreted for areas underlain by amphibolites. The wide variation of the geomorphology is the major factor that contributed to the favourable weathering development in areas underlain by gneisses. The abrupt changes in elevation facilitate mass movements of water and soils. Other factors are mineralogical and foliation attributes of gneisses that enables differential weathering and development of zones of weaknesses on the outcrops, which ensures further and ease break down and rock decomposition. The inclusion of dark-coloured minerals such as biotite in the mineral assemblage are also crucial for the complimentary development of thick weathered horizons in areas underlain by gneisses. However, saprolitic regolith units of gneissic bedrock areas are more sandy compared to amphibolite terrain.

For migmatite terrains, the thickness of regoliths is shallower when compared with those of amphibolites and gneisses, but the degree of basement fracturing is almost as high as that of the latter. The bedrock of $72 \%$ of the total VES surveys carried out on migmatites terrain are interpreted as either fractured or partly weathered basement. The thickness of the weathered layer ranges between 4.6 and $23.6 \mathrm{~m}$ (av. $12.77 \mathrm{~m}$ ). The lithologic distribution of the weathered layer is marked by dominant clayey soils, while sandy units are also fairly represented. The wide lithologic variation in migmatites is due to the fact that they are composite rocks of latter granitic intrusions upon the older rocks such as gneisses, and amphibolitic. This typified high contrast in geologic structures that are most often zones of structural weakness that favours easy breakdown of rock. Nonetheless, mineralogical assemblages of the rock have a lot of influence too on disintegration of mineral grains. The significant sandy saprolitic soils as interpreted for migmatites as well as for gneisses are as a result of proportionate abundance of early and late formed minerals.

Porphyritic granite terrains are the least fractured. About $20 \%$ of the surveyed area is interpreted as either being partially weathered or fractured. The degree of weathering development is also the least with an average of 11.29 $\mathrm{m}$ regolith thickness. The saprolite intermediate layer is also shallow, except at few locations at the central pass between the North and South hilly terrains escarpment where the thickness is higher than $10 \mathrm{~m}$. Areas with fairly thick regolith unit were also found around rock contacts in Idere. Conversely, areas with fractured bedrock are characterised by shallow regolith development as seen at Ayete and Jagunode. Generally, most areas underlain by porphyritic granite were high lying, but were markedly associated with fairly thicker top soil layer at an av. of 1.76 m. Considering the limited bedrock fractures, the saprolite though shallow appears to be the most likely groundwater zone for most areas underlain by porphyritic granite. The potential for groundwater occurrence is more favoured by the relatively more abundant of sandy soils development in the matrix-weathered layer, though clayey soils are also fairly represented. The coarser saprolite layer for areas underlain by porphyritic granite is owed to the greater abundance of more resistive minerals such as quartz in granite. Quartz mineral is known to be more stable to surface environmental processes such as erosion and weathering. Additionally, the lower extent of weathering can also be attributable to the massive textural arrangement of large grained mineral constituents of quartz and feldspars.

\subsection{Groundwater recharge potential across the various bedrock terrains}

The statistics of the Dar Zarrouk parameters are presented along with the primary geo-electric parameters in Table 1. The map of total longitudinal conductance from which recharge potential of the regolith units were inferred across the study area is presented in Fig. 4 . The total longitudinal conductance, $\mathrm{S}$ in mhos $(\Omega-1)$ ranged from 0.01 - 1.42 for all the bedrock settings. The average values were $0.45,0.28,0.23$ and 0.15 for amphibolites, gneisses, migmatites and porphyritic granite respectively. From Table 1, S ranged from 0.02 to 1.42 (av.0.45) in amphibolite terrains; for gneisses, 0.01 to 1.06 (av.0.28); for migmatite, 0.02 to 0.60 (av.0.23) and for porphyritic granite, 0.05 to 0.38 (av. 0.15$)$. 


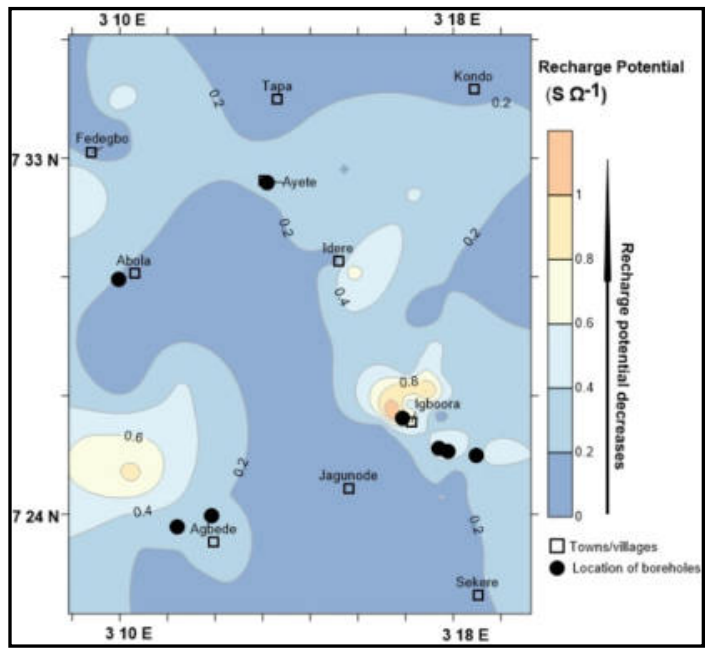

Fig. 4: Distribution of wells on groundwater recharge potential map

Areas with high S values are locations with low recharge potential and vice-versa for locations with low $\mathrm{S}$ values. The relatively higher mean value of $\mathrm{S}$ for amphibolite revealed deep weathering condition as well as development of high amount of fine grained weathered layer. However, water transmission in clayey regolith will be low, but the reasonable spread of bedrock fractures of about $44 \%$ of the area surveyed across amphibolite terrains is a good stand for being regarded as discharge areas with good groundwater potential. In addition, the fact that amphibolite terrains are characterised by thick weathered layer, though largely fine grained depicts good groundwater potential. Most terrains within gneisses and migmatite are within moderate conductance with average values of 0.28 and 0.23 respectively. Hence, these terrains can also be considered as having moderate recharge potential. Areas underlain by porphyritic granite at the north-central with average conductance of 0.15 mhos and other adjoining areas with less than 0.20 mhos can be regarded as locations with good groundwater recharge. Notwithstanding, terrains underlain by porphyritic granite are characterised by shallow regolith and less bedrock fractures. Hence, these locations cannot be regarded as having good potential for groundwater since water supply may not be sustainable.

In respect of electric conductance, saturated clayey units will be good conductor, but in hydrogeological sense, clayey regolith have poor water transmission capacity. Hence, the thicker and more clayey the regolith, the higher the conductance and the less the ability of the regolith to transmit water. Therefore, areas classified as having moderate to high conductance are more widespread since the weathered units across the study area are mostly clayey. This is more so in locations underlain by amphibolite at Igboora, gneisses and rock boundary areas at Idere where $\mathrm{S}$ is high - moderate (Fig. 4).

The recharge potential of the areas underlain by amphibole rich bedrocks is high, due to the thick and more conductive regolith development, and occurrence of fractured bedrock settings in the area. However, the occurrence of groundwater within the saprolitic layer will be subject to direct water recharge due to thin top soil cover which ranges from $0.4-5.8 \mathrm{~m}$ (av. $1.68 \mathrm{~m}$ ). The potential for water conductance as interpreted from the total longitudinal conductance also varies widely for gneisses. Though, the weathered layer is relatively thicker, the disparity in the recharge potential is owed to the large variations in the resistivities of the top soils and the saprolite regolith units. The standard deviations obtained for the geo-electric parameters (Table 1) for gneisses are all large as compared to other bedrocks.

In locations underlain by migmatite, the recharge potential as interpreted from the total longitudinal conductance is low with range of $0.02-0.60$ mhos (av.0.23mhos) and these areas are categorized to have low - moderate potential. In porphyritic granitic terrain, the longitudinal conductance varies from $0.05-0.38$ mhos with an average of 0.15 mhos, and it is the lowest for all the bedrocks. The granitic bedrock is considered to be closer to the surface in these areas as compared to areas underlain by other bedrocks. Hence, the potential for groundwater recharge is regarded to be low in porphyritic granitic terrain. The transverse resistance for all the bedrocks ranges from low to moderate. 


\subsection{Aquifer transmissivity and sust}

ainability

About one-third of all the wells tested have sustainable yield and are found in areas underlain by amphibolites and gneisses, except the one located at Ayete that is on granitic terrain (Fig. 4). The estimable hydraulic parameters of the prolific wells are outlined in Table 2. From all the tested wells, only one is within granitic terrain at Ayete. All other wells with sustainable yield were found in areas underlain by amphibolite and gneisses. Groundwater discharge was between 32.78 and $93.58 \mathrm{~m} 3 /$ day, while the aquifer transmissivity ranges from 0.50 to $7.75 \mathrm{~m} 2 /$ day. Well with the highest discharge of $93.58 \mathrm{~m} 3 /$ day and transmissivity of $5.53 \mathrm{~m} 2 /$ day is at Ajegunle with a depth of just $18.9 \mathrm{~m}$; however, the depths of most sustainable prolific wells were within $30-38 \mathrm{~m}$. Hence, wells yield in these areas is expected to be high if the wells penetrate the fractured zones. Wells that are prolific were found to be within zones of moderate - high conductance (Fig. 4), characterized by thick fine grained overburden layer with numerous bedrock fractures. These locations are mostly within areas underlain by amphibolite and gneisses.

From this results it is obvious that areas underlain by migmatte and porphyritic granite are the recharge zones characterised by lesser developed but coarser grained weathered layer and lower bedrock fractures. The yield of wells in these communities that include Tapa, Ayete etc were found to be unsustainable as a result of sharp drawdown and water cessation during pumping. On the other hand, locations underlain by amphibolite and gneisses were marked by most by wells with good yield that are sustainable. This is due to occurrences of more numerous bedrock fractures and thicker development of weathered layer. These locations are the viable discharge areas in the region.

Table 2: Hydraulic properties of sustainable aquifers in the area

\begin{tabular}{|lllllll|}
\hline s/n & Well location & $\begin{array}{l}\text { Elevation } \\
(\mathrm{m})\end{array}$ & $\begin{array}{l}\text { Well depth } \\
(\mathrm{m})\end{array}$ & Discharge $\left(\mathrm{m}^{3} /\right.$ day $)$ & $\begin{array}{l}\text { Transmissivity } \\
\left(\mathrm{m}^{2} / \text { day }\right)\end{array}$ & $\begin{array}{l}\text { Underlying } \\
\text { Bedrock }\end{array}$ \\
\hline $\mathbf{1}$ & Pako & 187 & 31.6 & 73.24 & 4.88 & Amphibolite \\
$\mathbf{2}$ & Igboole I & 170 & 38.0 & 71.93 & 7.75 & Amphibolite \\
$\mathbf{3}$ & Igboole II & 175 & 30.4 & 67.92 & 1.11 & Amphibolite \\
$\mathbf{4}$ & Ajegunle & 159 & 18.9 & 93.58 & 5.53 & Amphibolite \\
$\mathbf{5}$ & Abola & 171 & 34.1 & 32.78 & 0.55 & Gneisses \\
$\mathbf{6}$ & Apata & 139 & 38.0 & 37.87 & 0.50 & Gneisses \\
$\mathbf{7}$ & Agbede & 143 & 34.6 & 78.92 & 7.23 & Gneisses \\
$\mathbf{8}$ & Ayete I & 141 & 28.0 & 56.81 & 1.21 & Granite \\
\hline
\end{tabular}

\section{Conclusion}

Previous works (Oladapo, and Akintorinwa, 2007; Jayeoba and Oladunjoye, 2013) ascribed high longitudinal conductance to zones with poor potential for groundwater as a result of coarseness of regolith units alone without recourse to the bedrock resistivity. This phenomenon could be explained from the formula for estimating the total longitudinal conductance (S) from which the recharge potentials are derived. Total longitudinal conductance is derived from the summation of the ratios of respective layer's thickness and its corresponding resistivity in a geoelectric sequence. The bedrock resistivity being the infinity layer is unquantifiable, hence it is not among the factors that define the longitudinal conductance from which the recharge potential of each VES point is described. For the present work, areas with thick clayey overburden units and high S values are those characterised by more fractured bedrocks that prominently influence the sustainability of groundwater. The transmissivity of the aquifers also revealed that fractured bedrocks are dominant transmitting medium for groundwater. Bedrock fractures are more determinant factor of groundwater sustainability than the overlying regolith units in basement areas of Ibarapa region. This studies also indicated that basement crusts that are characterised by thick clayey-silty regolith units are more likely to terminate on fractured bedrocks.

This present work also revealed that the overburden units may not be the main or dominant passage for 
groundwater recharge. Rock contacts and subsurface fractures are also paramount channel of water infiltration in basement terrains through which water seeps or recharges the fractured bedrocks overlaid by thick fine grained overburden.

\section{Acknowledgements}

The Author wishes to acknowledge the kind people of Ibarapa regions, most especially Mr. Ayoade the owner of Joy Crown Hotel at Igboora for the rebate he granted the Author during his stay in the period of data acquisition. Also, the morale support of Mrs. Oluwatosin Akanbi ACA ensured the final completion of the research.

\section{References}

Abiola, O., Enikanselu, P. A. and Oladapo, M. I. 2009. Groundwater potential and aquifer protective capacity of overburden units in Ado-Ekiti, southwestern Nigeria. International Journal of Physical Sciences 4.3: 120-132. Retrieved May 18, 2011, from http://www.academicjournals.org/IJPS.

Akanbi, O.A. (2017). Hydrogeologic characterisation of crystalline basement aquifers of part of Ibarapa area, southwestern Nigeria. Ph.D. thesis. Department of Geology, University of Ibadan. Xxiv + 312pp.

Akanbi, O.A. (2018a). Hydrogeological characterisation and prospects of basement aquifers of Ibarapa region, SW- Nigeria. Applied Water Sci (2018) Vol. 8(3), 89. Springer- Berlin Heidelberg 2190-5495 (Online). DOI: https://doi.org/10.1007/s13201-018-0731-9.

Akanbi, O.A. (2018b). Groundwater Occurrence from Hydro-geomorphological Study of Hard Rock Terrain of part of SW Nigeria. RMZ- Material and Geo-environment. Vol. 65:3,131-144. https://doi.org/10.2478/rmzmag2018-0011.

Aweto K.E. 2011. Aquifer vulnerability assessment at Oke-Ila area, southwestern Nigeria. International Journal of the Physical Sciences 6.33: 7574-7583. Retrieved Jan. 17, 2012, from http://www.academicjournals.org/IJPS.

Jayeoba A., and Oladunjoye, M. A. 2013. Hydro-geophysical evaluation of groundwater potential in hard rock terrain of southwestern Nigeria. RMZ- Materials and Geo-environment 60:271-284.

Kruseman, G. P. and de Ridder, N. A. 2000. Analysis and evaluation of pumping test data. 2nd edition. Wageningen: International institute for land reclamation and improvement.

NGSA, 2009. Geological and mineral resources map of south-western zone, Nigeria. Abuja:NGSA.

Offodile, M. E. 2002. Ground water study and development in Nigeria. 2nd edition. Jos: Mecon geology and engineering services limited.

Oladapo, M. I. and Akintorinwa, O. J. 2007. Hydrogeophysical study of Ogbese southwestern Nigeria. Global journal of pure and applied sciences 13.1: 55-61.

Olayinka, A. I and Mbachi,C. N. C. 1992. A technique for the interpretation of electrical soundings from crystalline basement areas of Nigeria. Journal of Mining and Geology, 28.2: 273-281.

Olorunfemi, M. O. and Olorunniwo, M. A. 1985. Geo-electric parameters and aquifer characteristics of some parts of southwestern Nigeria. Geologia Applicata E. Idrogeologia, 20: 99-109.

Olorunfemi, M. O. and Olorunniwo, M. A. 1990. The determination of the geo-electric parameters of some Nigerian residual and detrital clays. Journal of Mining and Geology, 26.1: 81-85.

Papadopulos, I. S. and Cooper, H. H. 1967. Drawdown in a well of large diameter. Water resources research 3.1: 241- 244.

Sabnavis M., and Patangay, N.S. 2006. Principles and Application of groundwater geophysics. Association of exploration geophysicists, Hyderabad, India.

Singhal, B. B. S. and Gupta, R. P. 1999. Applied hydrogeology of fractured rocks. Dordrecht, The Netherlands: Kluwer Academic Publishers.

Dr. Olanrewaju A. Akanbi is presently the Ag. Head of Department of Earth Sciences of Ajayi Crowther University, Oyo, Nigeria and a registered Geoscientist (COMEG). 